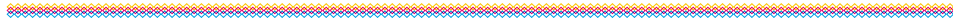

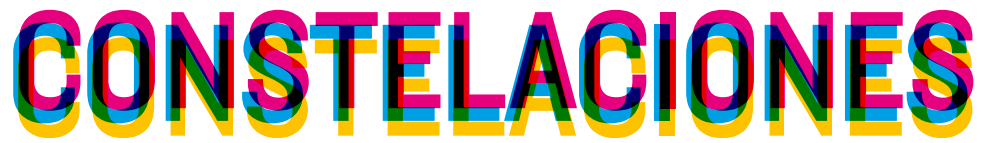

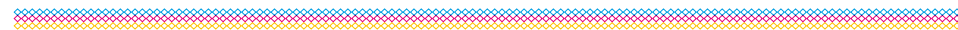




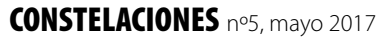

Revista de Arquitectura de la Universidad CEU San Pablo

Architecture Magazine of CEU San Pablo University

Periodicidad anual

Annual periodicity

COMITÉ DE REDACCIÓN EDITORIAL COMMITTEE

\section{Dirección Directors}

Juan García Millán

Santiago de Molina

Jefa de Redacción Editor in Chief

Covadonga Lorenzo Cueva

Secretario de Redacción Editorial Clerk

Rodrigo Núñez Carrasco

Maquetación y producción Design and production

María Fernández Hernández

Clara Martínez-Conde Rubio

Revisión de textos en inglés English Editing

Carlota Sáenz de Tejada Granados

Responsable Web Web Page Manager

María Isabel Castilla Heredia

Diseño Original Original Design

Juan Roldán Martín

\section{Vocales Board Members}

María Dolores Gómez Pulido. Escuela Politécnica Superior, Universidad CEU San Pablo, Madrid

Rocío Carvajal Alcaide. Escuela Politécnica Superior, Universidad CEU San Pablo, Madrid

Clara Eugenia Maestre Galindo. Escuela Politécnica Superior, Universidad CEU San Pablo, Madrid

\section{CONSEJO EDITORIAL EDITORIAL BOARD}

Beatriz Colomina. School of Architecture, Princeton University, New Jersey

Carmen Díez Medina. Escuela de Ingeniería y Arquitectura, Universidad de Zaragoza

María Antonia Frías Sargadoy. Escuela Técnica Superior de Arquitectura, Universidad de Navarra

Juan Miguel Hernández Léon. Escuela Técnica Superior de Arquitectura, Universidad Politécnica de Madrid

Juan José Lahuerta Alsina. Escuela Técnica Superior de Arquitectura, Universidad Politécnica de Cataluña, Barcelona

Eduardo Leira Sánchez. Ex director del Plan General de Ordenación Urbana, Madrid

Joaquín Medina Wamburg. Facultad de Aquitectura Diseño y Urbanismo, Universidad de Buenos Aires

Zaida Muxí Martínez. Escuela Técnica Superior de Arquitectura, Universidad Politécnica de Cataluña, Barcelona José Joaquín Parra Bañón. Escuela Técnica Superior de Arquitectura, Universidad de Sevilla

Víctor Pérez Escolano. Escuela Técnica Superior de Arquitectura, Universidad de Sevilla

Fernando Pérez Oyarzún. Escuela de Arquitectura y Diseño, Pontificia Universidad Católica, Santiago de Chile Judith Sheine. School of Architecture and Allied Arts, University of Oregon, Portland

Andrés Walliser Martínez. Global Design, New York University, Nueva York

\section{ISSN 2340-177X}

Depósito legal M-13872-2013

(c) de los textos, sus autores

(c) de las imágenes autorizadas

(C) Revista Constelaciones

๑) Escuela Politécnica Superior, Universidad CEU San Pablo

Universidad CEU San Pablo

Escuela Politécnica Superior

Urbanización Montepríncipe, s/n

Alcorcón, 28925. Madrid (España)

constelaciones@eps.ceu.es

www.uspceu.es

www.revistaconstelaciones.wordpress.com

Edición Edition

Fundación Universitaria San Pablo CEU

Madrid, España

Impresión Printing

VA Impresores

Impreso en España Printed in Spain

Distribución Distribution

CEU Ediciones

\author{
INDEXACIÓN INDEXING \\ Índices Index \\ Latindex \\ Avery Index \\ ErihPlus \\ MIAR
}

Bases de datos Data bases

Dialnet

Índices en evaluación Evaluation Index

Web of Science

Scopus

Dulcinea

EBSCO

Sherpa Romeo
Los textos que componen Constelaciones se obtienen mediante convocatoria pública. Para que los trabajos recibidos entren en el proceso de selección de los artículos a publicar deben ser trabajos originales no publicados anteriormene, con una extensión recomendada de 3.000 palabras, título, resumen (un máximo de 150 palabras) y palabras clave (un mínimo de cuatro palabras), en español y en inglés. Tras haber cumplido estos requisitos (y los correspondientes incluidos en las normas editoriales de la revista, disponibles para consulta en formato digital desde el comienzo de la convocatoria), tiene lugar un proceso de revisión y evaluación de los artículos previa aceptación de los mismos para su publicación. Para acometer dicho proceso, y con el fin de asegurar la calidad de los contenidos, la revista Constelaciones recurre a evaluadores externos a la institución editora y anónimos (cada artículo es evaluado por dos de ellos) encargados de someter a crítica los mismos. Todos los artículos de investigación publicados en esta revista han pasado por dicho proceso. La recepción de artículos se extendió hasta el 30 de septiembre de 2016. Texts included in Constelaciones are obtained by public announcement. Only original papers that have not been previously published will be included in the process of selection of articles. They should not exceed 3.000 words and should include a title, an abstract (no more than 150 words) and keywords (a minimum of four words), in Spanish and English. After having fulfilled these requirements (and those included in magazine editorial standards, available for consultation from the beginning of the Call for Papers), occurs a process of review and evaluation of articles upon acceptance of them for publication. To undertake this process, and in order to ensure the quality of the contents, Constelaciones turns to external and anonymous evaluators to the institution (each article is evaluated by two of them) responsible for the critic. All the articles published in this journal have undergone this process. The deadline for reception was extended until September 30, 2015.

Todos los derechos reservados. Esta publicación no puede ser reproducida, ni en todo ni en parte, ni registrada, ni transmitida, ni almacenada en ninguna forma ni por ningún medio, sin la autorización previa y por escrito del equipo editorial. En este número se han utilizado algunas imágenes de las que no se ha podido identificar al propietario de los derechos. En estos casos hemos entendido que las imágenes son de libre uso. En caso de identificar alguna de estas imágenes como propia, por favor, póngase en contacto con la redacción de Constelaciones. Los criterios expuestos en los diversos artículos de la revista son responsabilidad exclusiva de sus autores y no reflejan necesariamente los que pueda tener el equipo editoral. El equipo editorial de la revista no se responsabiliza de devolver la información enviada a la redacción a no ser que se le solicite expresamente. All rights reserved. This publication cannot be reproduced, in whole or in part, nor registered, transmitted or stored in any form or by any means, without the written permission of the Editorial team. In this issue some images were used without knowing the owner of the rights. In these cases, we have understood that the images are free of use. In case you identify written permission of the Editorial team. In this issue some images were used without knowing the owner of the rights. In these cases, we have understood that the images are free of use. In case you identify
any of these images as your own, please, contact with the Editorial staff of Constelaciones. The opinions expressed in this issues's articles are entirely the responsibility of their authors and are not necessarily shared by the editors of this journal. The publisher don't take responsibility for returning submitted material which is not expressly requested. 

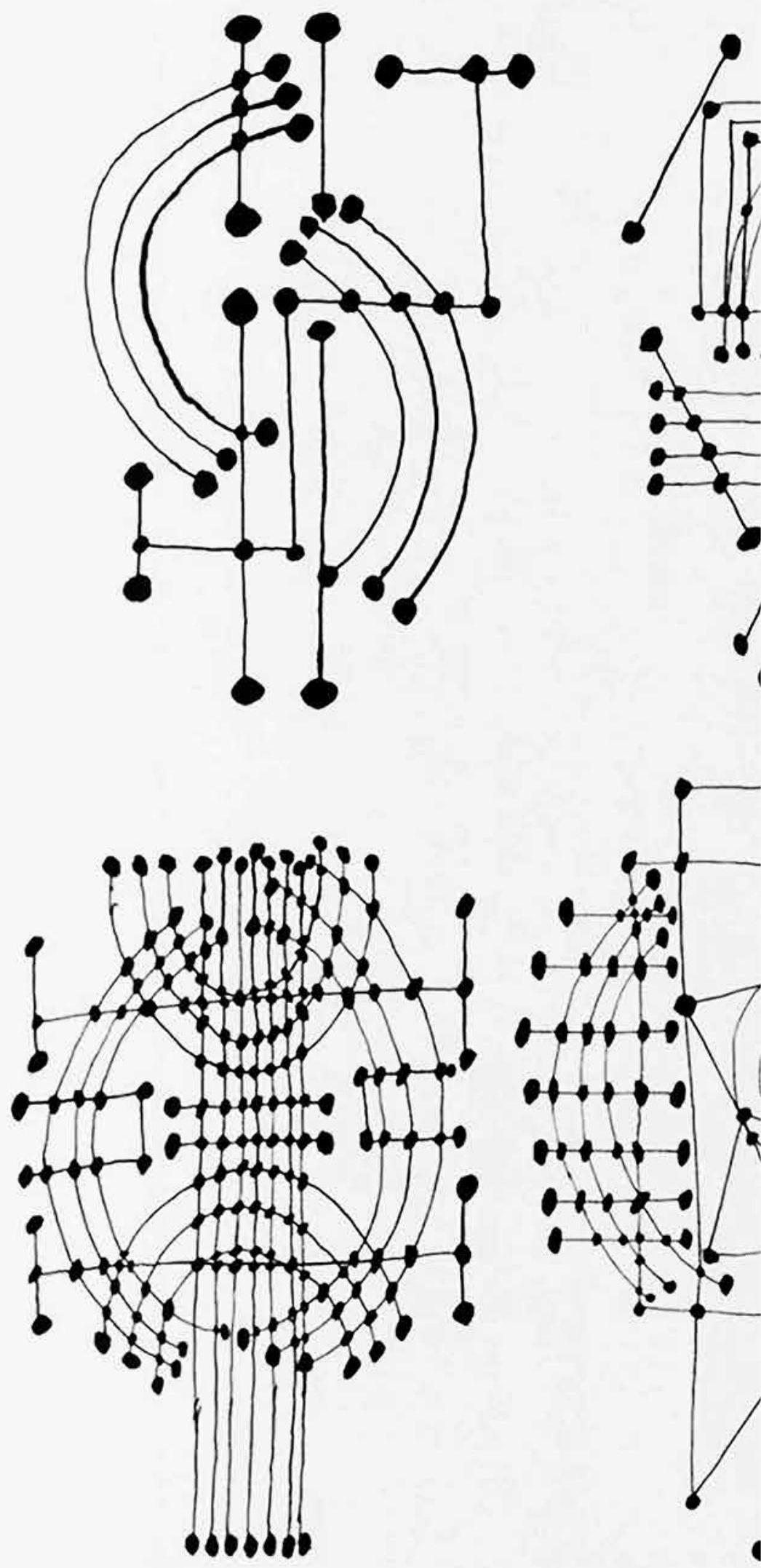


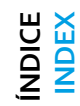

จ

ก)

品

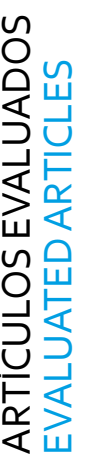

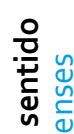

बํำ

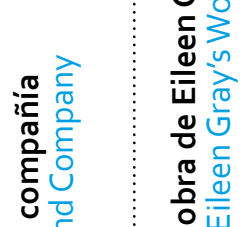

드.

ฮั

茄

:

ที่ ปั อ

苦云

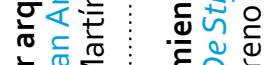

过

ह $\frac{2}{3}$

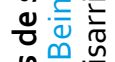

눈

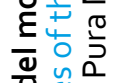

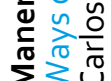

นับ

음

๗ั

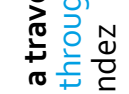

号

궁워

뜬

원

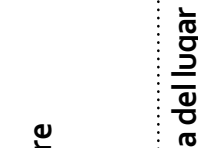

임

ส

응

离

$: \frac{\mathscr{2}}{ \pm}$

을

tั

ग

ํํำ

ํㅡㄹ

:

응 $\frac{\cup}{0}$

บับ

인

든

冚

号京

ब

ฮั

을

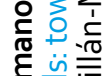

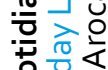

언

으 $\frac{\pi}{\pi}$

产

등 똥

告崖

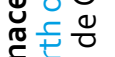

ํํㄴ

일

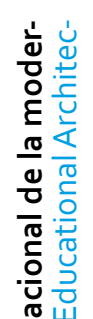

高
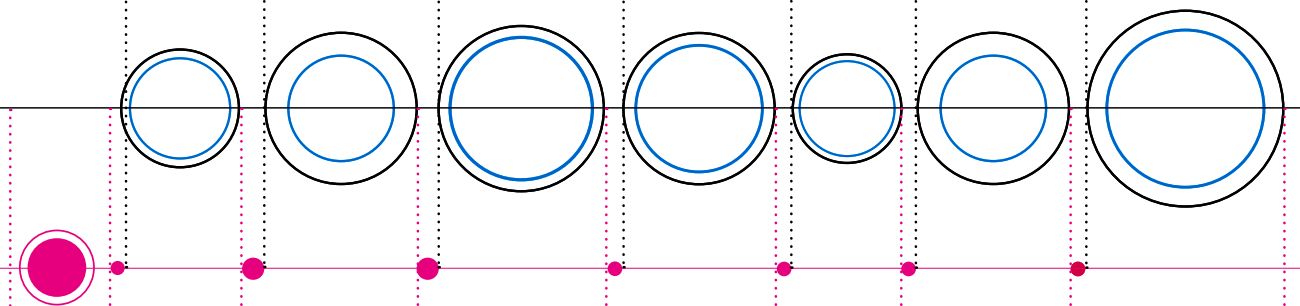

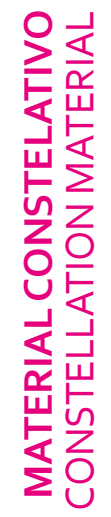

岂㟧

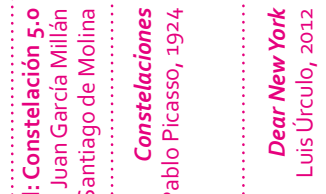

$=\quad \stackrel{m}{\sim}$

$\stackrel{\bullet}{v}$
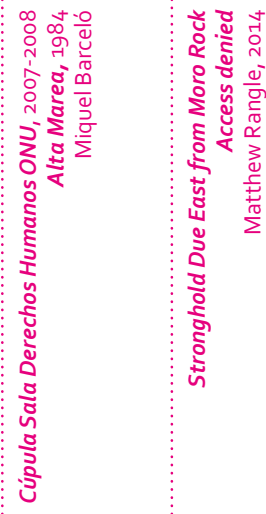

$\overline{6}: \AA$

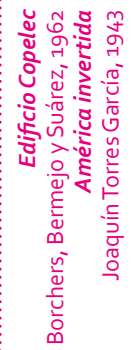

$\infty$

응 


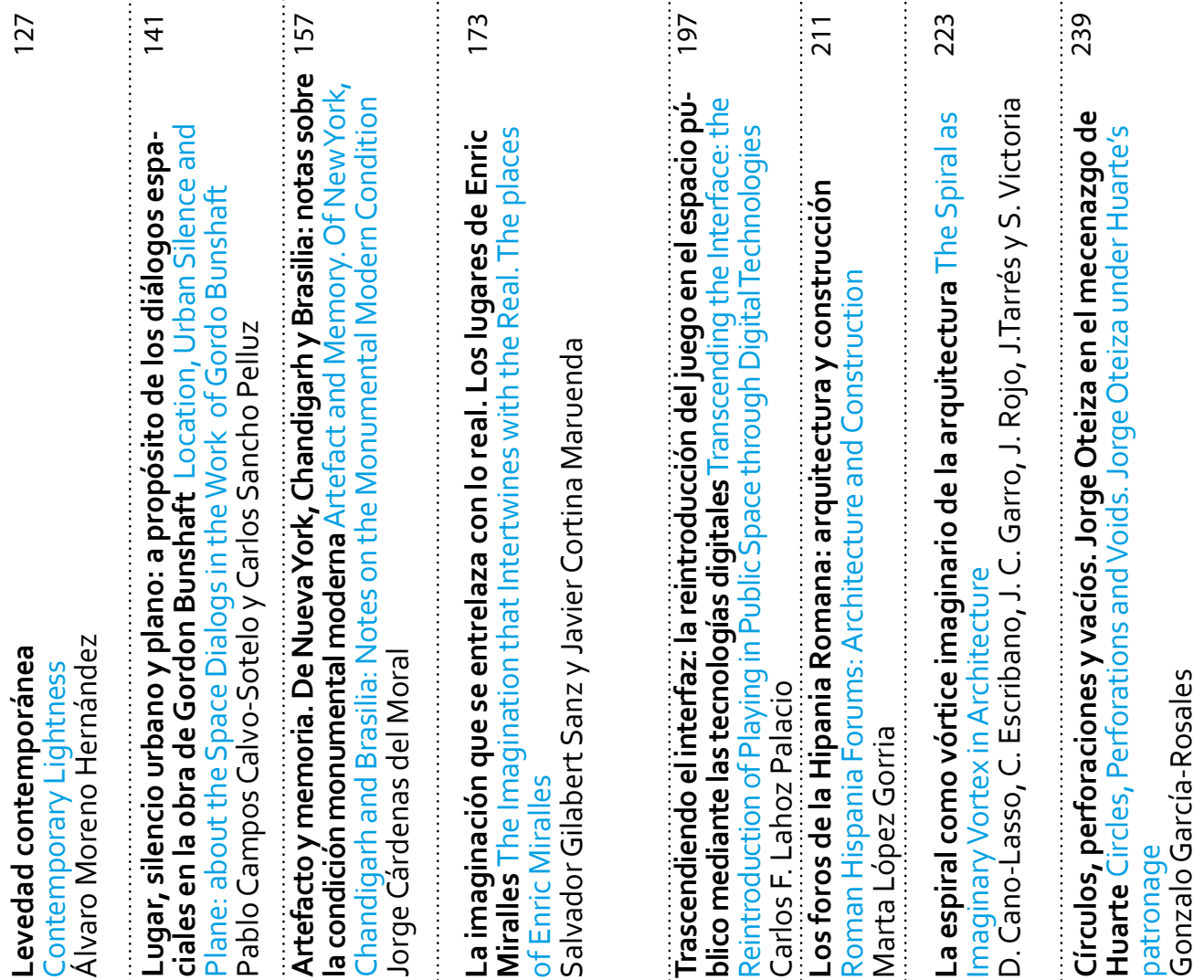
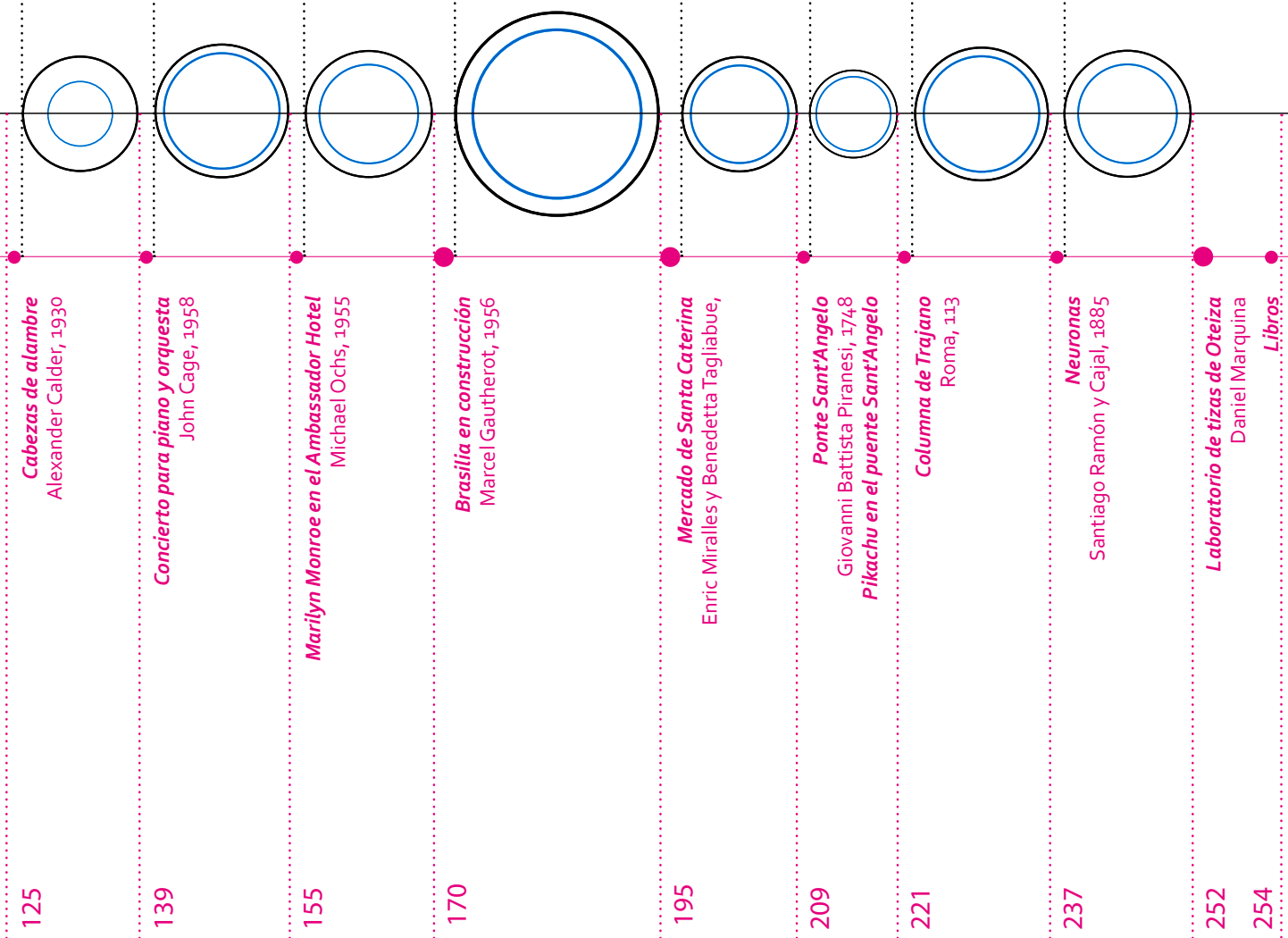


\title{
Círculos, perforaciones y vacíos. \\ Jorge Oteiza en el mecenazgo de Huarte
}

Circles, Perforations and Voids.

Jorge Oteiza under Huarte's Patronage

\author{
Gonzalo García-Rosales \\ Escuela Técnica Superior de Arquitectura, Universidad Politécnica, Madrid \\ Escuela Técnica Superior de Arquitectura, Universidad de Alcalá, Madrid \\ Traducción Translation Servicio de traducción de la Universidad de Alcalá
}

Palabras clave Keywords

Arte, vacío, mecenazgo, experimentar, Huarte, Jorge Oteiza, Le Corbusier

Art, void, patronage, experiment, Huarte, Jorge Oteiza, Le Corbusier

\section{$\underline{\text { Resumen }}$}

La arquitectura y las artes visuales experimentales en España en los años cincuenta y sesenta ofrecen múltiples posibilidades de análisis aun por descubrir. Entre ellas, merece especial atención el mecenazgo de la familia de industriales Huarte, promotores de una labor creativa sin precedentes. Una de las figuras clave fue el escultor Jorge Oteiza, perteneciente al círculo de los mecenas, gran activador de la cultura española de aquellos años y sobre todo, uno de los grandes impulsores de la labor de los mecenas. Desvelar algunas conexiones que se establecieron entre su obra y la de arquitectos como Sáenz de Oíza o Corrales y Molezún, así como la posible influencia recibida por Le Corbusier en sus esculturas conclusivas finales ha sido el objetivo prioritario de este trabajo.

\section{Abstract}

Architecture and the experimental visual arts in Spain in the fifties and sixties provide many opportunities for analysis that have yet to be discovered. Among these, the patronage by the Huarte family of industrialists, as sponsors of unprecedented creative work warrants special attention. The sculptor Jorge Oteiza, a member of the patrons' circle, was the great driving force behind Spanish culture in those years and one of the major instigators of the work of the patrons. The main objective of this study is to highlight some of the links between his work and the work of architects such as Sáenz de Oíza and Corrales y Molezún, as well as the possible influence of Le Corbusier in his conclusive final sculptures. 
Matar al padre. La constructora Huarte y Cía fue fundada por D. Félix Huarte en 1927, ejecutando obras importantes en el Madrid de la Segunda República, como el Frontón Recoletos o la Facultad de Filosofía y Letras, entre otras, aunque fue a partir de 1940 cuando se estableció como una de las grandes constructoras del país, responsable de obras de enorme trascendencia para la imagen del régimen franquista, como fue el Valle de los Caídos, el Ministerio del Aire o la Sede de los Nuevos Ministerios en Madrid. Fue D. Félix un hombre hecho a sí mismo, y quizá por ello extremadamente duro y exigente. Ejerció el rol de padre todopoderoso, recto y severo con sus cuatro hijos, en especial con los tres varones, quienes aun muy jóvenes asumieron papeles de gran responsabilidad en la dirección de las empresas familiares.

Uno de los grandes valores que supo transmitirles fue la pasión por el arte y el coleccionismo. Reunió una amplia colección de pinturas de algunos de los más destacados pintores figurativos del momento, figurando Pancho Cossío, Rafael Zabaleta o Benjamín Palencia entre sus autores preferidos. Años más tarde, su hijo Juan se jactaba entre risas de haber escandalizado a su padre al enterarse del precio que había pagado por un cuadro de Lucio Fontana, un lienzo enteramente blanco con sólo unos cortes verticales en la tela. "Mi hijo está loco", llegó a exclamar D. Félix. Pero ese comentario denotaba en Juan, un claro sentimiento de culpabilidad ante el juicio paterno, pues el padre jamás llegó a aprobar plenamente sus criterios plásticos. Todos los hijos de D. Félix -Jesús, Juan, María Josefa y Felipe- se convirtieron en grandes coleccionistas y mecenas promoviendo a los artistas contemporáneos más experimentales del momento, por entonces casi unos desconocidos. Sus colecciones cuentan con obras fundamentales de Jorge Oteiza, Eduardo Chillida, Pablo Palazuelo, Antoni Tàpies, o Néstor Basterretxea.

La casa, un refugio espiritual. Como grandes coleccionistas y patrocinadores artísticos, los cuatro hermanos -ricos, cultos, refinados- mantuvieron un deseo permanente de rodearse de obras de arte, reacción producida por un entorno hostil tanto ideológico como físico o moral. En el interior del domicilio madrileño de Juan Huarte, las obras de arte dominan el espacio
Fig. 1. Dolcet, Juan: Interior de la vivienda de Juan Huarte, s.d.

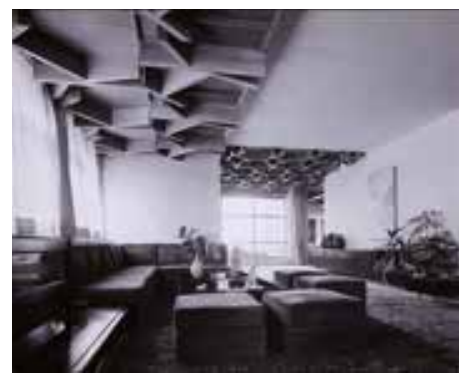

Killing the Father. The construction company Huarte y Cía was founded by Felix Huarte in 1927, and carried out major projects in Madrid during the Spanish Second Republic, including the Recoletos Fronton and the Faculty of Philosophy and Arts, among other projects. However, it became consolidated as one of Spain's largest construction companies from 1940 onwards, and was responsible for works that were very important for the image of the Franco regime, including the Valley of the Fallen Monument, the Air Ministry and the Nuevos Ministerios Government Offices in Madrid. Felix Huarte was a self-made man, and was perhaps extremely strict and demanding as a result. He played the role of an all-powerful father, who was upright and severe with his four children and especially with his three sons, who from very young, assumed roles of great responsibility in the management of the family's businesses.

One of the major values that he conveyed to them was his passion for art and collecting. He assembled a large collection of paintings by some of the most important figurative painters of the time and Pancho Cossio, Nicanor Zabaleta and Benjamin Palencia were among his favourite artists. Years later, his son Juan laughingly boasted of how his father was outraged when he heard about the price he had paid for a painting by Lucio Fontana, a completely white canvas with only vertical cuts in the fabric. "My son is mad", exclaimed Felix. However, that comment showed that Juan clearly felt guilty before his father's judgement, as his father never fully approved of his artistic opinions. All of Felix's children -Jesús, Juan, María Josefa and Felipe- became great collectors and patrons, supporting the most experimental contemporary artists of their day, who at that time were almost unknown. Their collections include seminal works by Jorge Oteiza, Eduardo Chillida, Pablo Palazuelo, Antoni Tàpies and Nestor Basterretxea. 

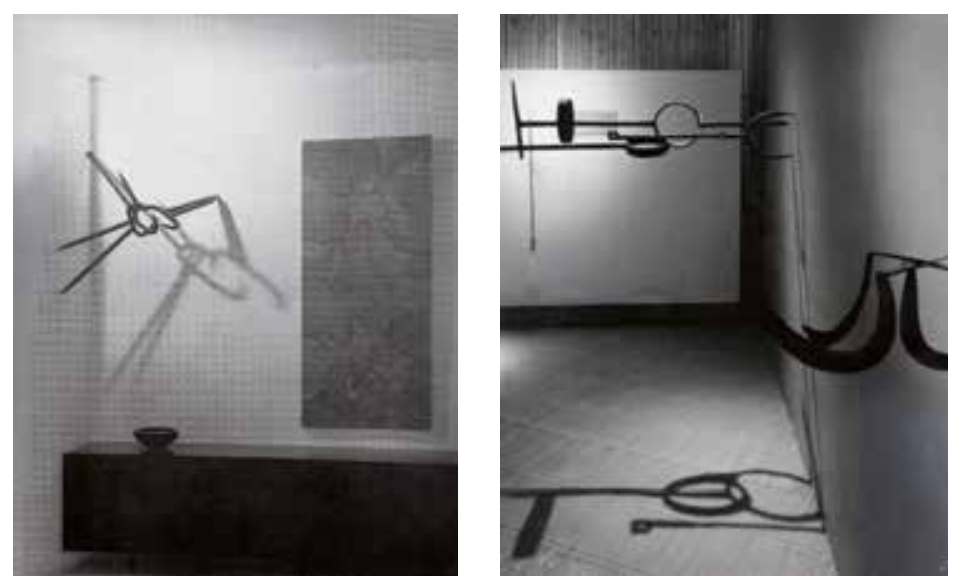

Fig. 2. Jiménez, L.: Escultura de Eduardo Chillida en el domicilio de Juan Huarte, 1966

Fig. 3. Escultura de Eduardo Chillida en el pabellón de España en la X Trienal de Milán, 1954.

-en techo, paredes y suelo- hasta el punto de resultar abrumador por la cantidad y calidad de las piezas exhibidas. (Fig. 1) En la imagen tomada por Juan Dolcet en los años sesenta, (1) vemos el célebre artesonado en madera de palosanto de Pablo Palazuelo, diseñado ex profeso para el lugar. En la pared derecha se distingue el óleo Le grand étude (1957-58), también de Palazuelo y repartidos por la sala piezas fundamentales de Oteiza como La tierra y la luna (1955), de Chillida como Música de las esferas I (1953), de Ángel Ferrant como Grupo 47 (1947) y un conjunto de cerámicas de Josep Llorens Artigas sobre un aparador de Esteban Vicente. Los visilllos, siempre cerrados, ocultan las espléndidas vistas exteriores, pues sólo la belleza del arte parece interesar a sus moradores. Uno de los rincones de la casa aloja una escultura en hierro de Chillida, Espíritu de los pájaros II (1955) (Fig. 2) dispuesta e iluminada de forma similar a las piezas del mismo autor mostradas en el Pabellón español en la x Trienal de Milán de 1954, (Fig. 3) según diseño de Ramón Vázquez Molezún, asombrando al mundo entero por la modernidad de su propuesta. Cuatro de las esculturas expuestas pertenecían ya por entonces a Juan Huarte, proclamándose así el primer coleccionista del escultor.

Home, a Spiritual Refuge. As major collectors and patrons of art, the four rich, educated and refined siblings had a permanent desire to surround themselves with works of art, in a reaction to an environment that was hostile ideologically, physically and morally. Works of art dominated the space inside the Madrid home of Juan Huarte -on the ceiling, walls and floor- to the point of being overwhelming in terms of the amount and quality of the pieces on display. (Fig. 1) In the photograph taken by Juan Dolcet in the sixties, (1) we can see the famous coffered wooden ceiling by Pablo Palazuelo, designed specifically for the room. On the right hand wall is the oil painting Le grand étude, from 1957-58, also by Palazuelo, and scattered around the room are important pieces including Earth and moon, by Oteiza dating from 1955, Music of the spheres I by Chillida, from 1953, Group 47 by Ángel Ferrant from 1947 and a set of ceramics by Josep Llorens Artigas on a dresser by Esteban Vicente. The lace curtains, which are all closed, hide the splendid views of the exterior, as only the beauty of art appears to interest the inhabitants. One of the corners of the home houses a sculpture in iron by Chillida, The Spirit of the Birds II, from 1955, (Fig. 2) arranged and illuminated in a similar manner to the pieces by the same artist in the Spanish Pavilion at the X Milan Triennale in 1954, (Fig. 3) according to a design by Ramón Vazquez Molezún, which astounded the entire world with the modernity of its approach. Four of the sculptures in display belonged at that time to Juan Huarte, who thereby claimed to be the leading collector of the sculptor's works.

A similar atmosphere prevailed in Jesús Huarte's home in Puerta de Hierro neighbourhood, in Madrid, which was designed by José Antonio Corrales and Ramón Vázquez Molezún. In the lengthways cross-section created by the lounge and the main courtyard of the house, (Fig. 4) it is apparent how the terrain of the plot is artificially raised as terraces in order 


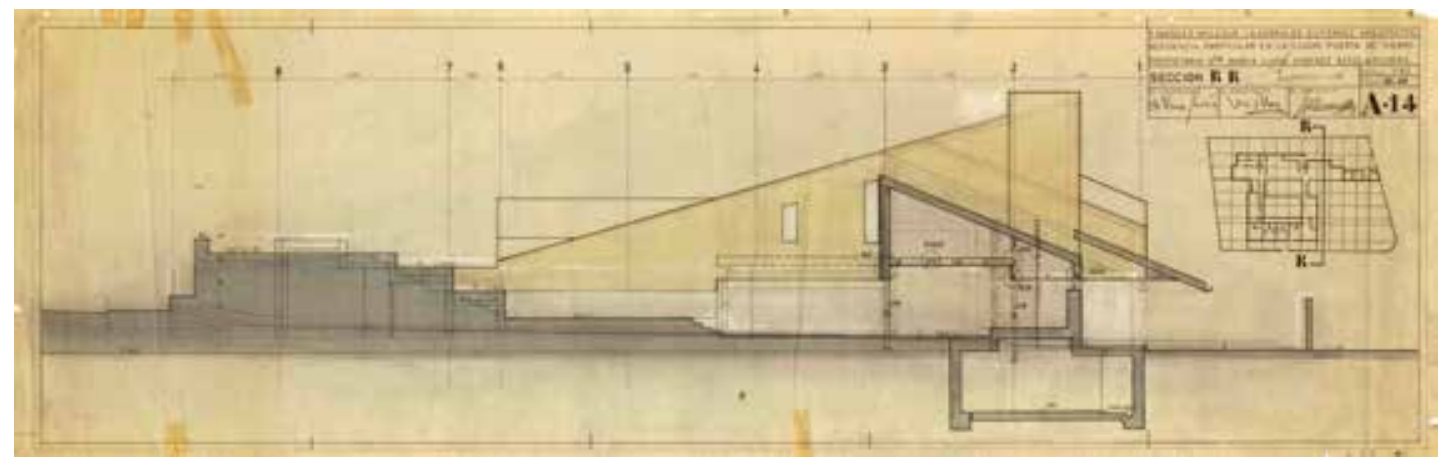

Algo similar sucedía en la Casa de Jesús Huarte en la Colonia Puerta de Hierro de Madrid, obra de José Antonio Corrales y Ramón Vázquez Molezún. En la sección longitudinal dada por el salón y el patio principal de

Fig. 4. Corrales, J.A.; Vázquez Molezún, R.: Sección longitudinal de la Casa de Jesús Huarte, 1965. la casa, (Fig. 4) vemos cómo el terreno de la parcela se eleva artificialmente de forma escalonada con objeto de aislar visual y acústicamente la vivienda del exterior, llegando a irritar a los vecinos que consideraban la casa un bunker cerrado sobre sí mismo.

La zona de estar vuelca sobre el patio más público, (Fig. 5) según la dirección marcada por la sección anterior. En este amplio jardín de vegetación exuberante descansaban varias esculturas, entre ellas las impresionantes Monumento al prisionero político desconocido (1965) (2) y Figura (1965), de Jorge Oteiza; una escultura abstracta de Carlos Ferreira, Torso $n^{\circ} 4$ (1972) y las fuentes-surtidores diseñadas por Pablo Palazuelo. El salón principal aloja un nicho encastrado junto a la chimenea donde se dispuso un sofá literalmente rodeado por lienzos abstractos del pintor Lucio Muñoz. (Fig. 6) Puede asegurarse que al igual que su hermano Juan, Jesús también organizó su paraíso doméstico donde nada del exterior le distraía, viéndose únicamente rodeado por bellas obras de arte y paisajes verdes cuidadosamente diseñados. Para los Huarte, pues, la casa

to isolate the home from the exterior both visually and acoustically, to the irritation of the neighbours, who considered the house an enclosed bunker.

The living area spills out onto the more public courtyard, (Fig. 5) in the direction marked by the previous section. There were several sculptures in this large garden of lush vegetation, including the impressive Monument to the Unknown Political Prisoner, (2) from 1965, and Figure, from 1965, by Jorge Oteiza, an abstract sculpture entitled Torso 4 by Carlos Ferreira dating from 1972, and fountain-jets designed by Pablo Palazuelo. The main room has a recessed alcove next to the fireplace, with a sofa that is literally surrounded by abstract canvases by the painter Lucio Muñoz. (Fig. 6) One can be sure that like his brother Juan, Jesús also organised his domestic paradise so that nothing from the outside world distracted him and he lived there surrounded only by beautiful works of art and carefully designed green landscapes. For the Huarte family, the home was therefore like a temple in which art, elevated to the status of a sacred object, was a vehicle that acted as a conduit towards aesthetic emotion and spiritual awe.

The Integration of the Arts. What was known as the Huarte group consisted of a small circle of architects, artists - painters, sculptors, filmmakers, designers, musicians and writers- who benefited from the patronage of Jesús and Juan Huarte. It included some of the leading Spanish artists of the time, who were mostly inclined towards experimentation and abstraction, (3) and were members of the European schools prevailing at that time. The affinity between the members of the group led them to experiment with other arts, and as such there were architects 


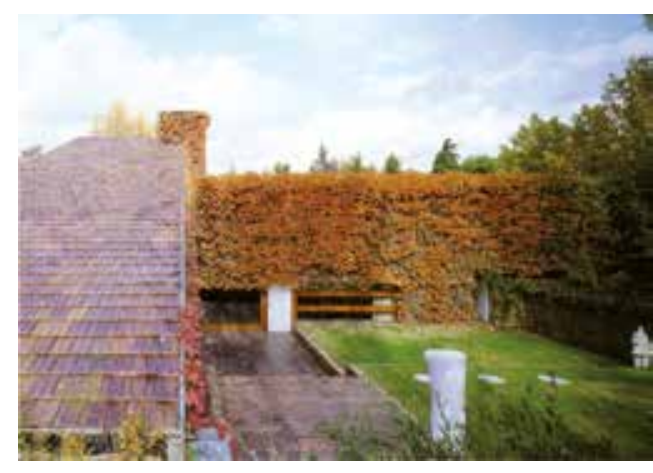

se entiende como un templo donde el arte, elevado a objeto sagrado, actúa como vehículo conductor hacia la emoción estética y el sobrecogimiento espiritual.

La integración de las artes. El conocido como grupo Huarte estaba compuesto por un conjunto reducido de arquitectos y artistas -pintores, escultores, cineastas, diseñadores, músicos y escritores- en torno al mecenazgo de Jesús y Juan Huarte. Allí se encontraban parte de los mejores creadores españoles del momento, mayoritariamente inclinados hacia la experimentación y la abstracción (3) e inscritos en las corrientes europeas del momento. La afinidad entre los integrantes del grupo les llevó a experimentar con otras artes, encontrando así arquitectos que pintaban, pintores que dirigían películas o escultores que diseñaban muebles, muy en la línea de integración de las artes promovida por los mecenas. Estos crearon la Sala de exposiciones HISA, (4) un espacio donde se expusieron -incluso simultáneamente- los productos industriales que fabricaban, las obras de aquellos artistas plásticos que apoyaban, los documentales que producían y los edificios que promovían y construían, ambientando el espacio con música contemporánea electroacústica financiada por ellos.
Fig. 5. Vista parcial del primer patio de la Casa de Jesús Huarte, Madrid, s.d.

Fig. 6. Vista parcial del interior de la Casa de Jesús Huarte, con pinturas de Lucio Muñoz, s.d.

who painted, painters who directed films, and sculptors who designed furniture, which was all very consistent with the integration of the arts encouraged by the patrons. They created the HISA Exhibition Hall, (4) a place which exhibited -sometimes simultaneously- the industrial products they manufactured, the works by the artists they supported, the documentaries they produced and the buildings they developed and built. The venue was given added atmosphere by contemporary electroacoustic music that they funded.

The sculptor Jorge Oteiza always stood out above all the others, and he had enormous authority over the group, giving guidance and advice and opening up avenues for investigation. His creative activity and maturity of thought peaked between 1954 and 1959, at the same time, not coincidentally, as the period when he worked most closely with Juan Huarte. Seldom in recent history has there been such a fertile relationship between an artist and his patron. It is surprising to consider the blind faith that the sponsor placed in the artist, funding all his projects and asking his advice on any matters he considered important. One wonders whether Oteiza's strong character, his determination and his moral rectitude reminded him of his father Felix. His profound admiration for the artist and the influence he allowed Oteiza to exercise appear to confirm this theory.

Holes, Voids and 'Condensers of Light'. After he returned to Spain in the late forties, Oteiza began to pursue lightness in his sculptures. He wrote: "The void must be the subject of a new plastic reasoning [...] the space will be the transition from a traditional statue-mass to the statue-energy of the future. From the heavy and closed statue to the light and open statue". (5) 
Por encima de todos ellos siempre destacó el escultor Jorge Oteiza, ejerciendo sobre el grupo una enorme autoridad, aconsejando, guiando y abriendo vías de investigación. Su momento de mayor actividad creadora y de madurez de pensamiento se desarrolló entre 1954 y 1959, coincidiendo, y no por casualidad, con el periodo de máxima colaboración entre él y Juan Huarte. Pocas veces a lo largo de la historia reciente se ha dado un caso de tanta fertilidad en la relación entre un creador y su mecenas. Sorprende comprobar la fe ciega que éste depositaba en él, financiando todos sus proyectos y pidiendo su consejo en cuantos asuntos consideraba importantes. Cabría preguntarse, ¿el carácter fuerte de Oteiza, su determinación y su fuerza moral, le recordaban a su padre, D. Félix? Su admiración profunda y la influencia consentida así parecen confirmarlo.

Agujeros, vacíos y 'condensadores de luz'. A partir de finales de los años cuarenta, una vez de vuelta a España, Oteiza comenzó a perseguir la ligereza en sus esculturas. Escribió: "El vacío ha de ser objeto de un nuevo razonar plástico [...] el hueco deberá constituir el tránsito de una estatua-masa tradicional a la estatua-energía del futuro. De la estatua pesada y cerrada a la estatua liviana y abierta". (5)

Poco más tarde hizo intervenir lo que quedó en llamar los 'condensadores de luz', unas perforaciones que practicaba en sus esculturas de tal modo que a través de ellas se liberaba energía, provocando una suerte de desmaterialización de la estatua, permitiéndole generar formas que tuviesen un significado espiritual, metafísico para el hombre contemporáneo. Se ha hablado de la influencia que Oteiza ejerció sobre los artistas españoles, pero poco sobre su influencia sobre los arquitectos. Cabría así establecer una conexión entre los 'condensadores de luz' de Oteiza y los tres patios de la Casa de Jesús Huarte. Estos se encuentran rodeados por el terreno artificialmente elevado, lo que provoca aun más la idea de hueco excavado en la tierra. La energía que emiten representa el alma de la casa, cada uno de ellos de manera diferente, atendiendo a una diferente categorización funcional en virtud de la privacidad de usos que les otorgan sus ocupantes.

Shortly afterwards, he began to produce what he decided to call 'condensers of light', perforations that he placed in his sculptures so that energy was released through them, leading to a type of dematerialisation of the statue, enabling it to generate forms that had a metaphysical and spiritual meaning for the contemporary man. There has been a great deal of discussion about Oteiza's influence on Spanish artists, but little about his influence on architects. It might thereby be possible to establish a link between Oteiza's 'condensers of light' and the three courtyards in the Jesús Huarte's House. The courtyards are surrounded by artificially high ground, which provides even greater encouragement for the idea of a void dug in the ground. The energy they give off is the soul of the house and each one does so differently, according to a different functional categorisation based on the privacy of uses conferred on them by their occupants. The plan of the ground floor (Fig. 7) clearly shows how the building is organised around these three perforations, and that the house not only adapts to their geometry, but also seems to take its meaning and strength from them.

Not surprisingly, in the opinion of its inhabitants, the dining room -the space under the large sloping roof, located between the first and second courtyard and open to both- (Fig. 8) is the most unusual place, and acts almost as a sacred space. Its wide perimeter windows placed at a height that is lower than normal enable those inside sitting around the table to admire the landscape. It does not seem coincidental that the highest part of this double-floor space was connected with the study of the house's owner, where he had his extensive library and a large grand piano. 
En el dibujo de la planta baja (Fig. 7) se percibe con claridad cómo el edificio se organiza alrededor de estas tres perforaciones, donde la casa no sólo se adapta a su geometría, sino que parece tomar su sentido y su fuerza.

No es de extrañar que según la opinión de sus moradores el comedor -espacio bajo la gran cubierta inclinada situado entre el primer y el segundo patio y abierto a ambos- (Fig. 8) sea el lugar más particular, actuando casi como un espacio sagrado. Sus ventanas perimetrales rasgadas y dispuestas a una altura inferior a lo normal, permiten admirar el paisaje sentados alrededor de la mesa. No parece casual que este espacio a doble altura comunicase en su parte más elevada con el estudio del dueño de la casa, donde contaba con su extensa biblioteca y un gran piano de cola.

Torres Blancas perforado. Las perforaciones sobre el lienzo -en forma de huecos, cortes o fisuras- se convirtieron en recurso frecuente en la abstracción de los años cincuenta. El salto al informalismo les permitió volcar en los cuadros una actitud violenta e inconformista provocada por la realidad que les tocaba vivir. Al mismo tiempo, la arquitectura empezó a evolucionar desde el funcionalismo racionalista al organicismo, provocando una actitud
Fig. 7. Corrales, J.A.; Vázquez Molezún, R.: Planta de cubiertas de la Casa de Jesús Huarte, 1965.

Fig. 8. Vista parcial del comedor de la Casa de Jesús Huarte, s.d.
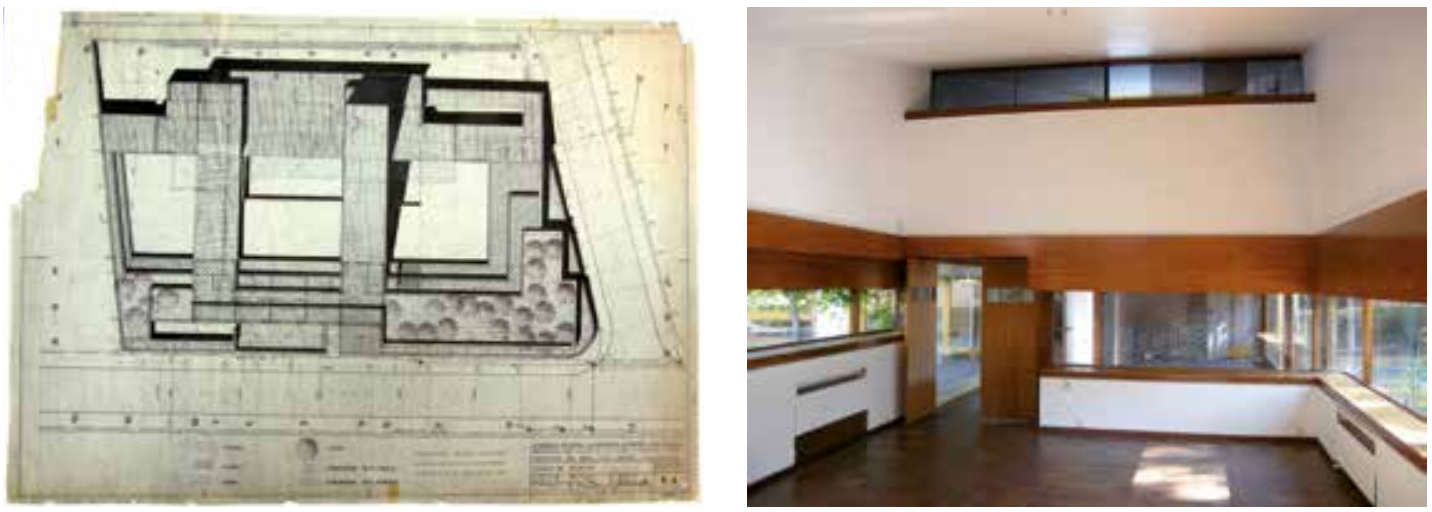

Torres Blancas Perforated. Perforations on canvas -in the form of holes, cuts or fissures- became a frequent motif in the abstraction of the 1950s. The shift to informalism enabled them to overturn a violent and non-conformist attitude caused by the conditions in which they live into their paintings. Meanwhile, architecture began to evolve from rationalist functionalism towards organicism, creating a more optimistic, freer attitude with more formal resources. This revolutionary spirit was quickly taken up by the members of the Huarte group and it became their hallmark.

The real estate boom led the Huarte family to create the HISA company in order to develop high-quality commercial buildings, using the best Spanish architects to do so. The first commission was Torres Blancas Building in 1958, the symbol of the company's creative work, which was completed ten years later. The industrialists used Oteiza's influence to recruit Saenz de Oíza, as the two men had previously worked together on the Sanctuary of Aranzazu. (6)

After HISA Exhibition Hall, all of the subsequent projects for Huarte were influenced by organicism, which was thereafter the lingua franca for the architects in the Huarte group. Torres Blancas was undoubtedly the building that made the biggest contribution to the transition to organicism in Spain, as part of its graphic documentation was first published in 1963, five years before the work was completed. (7) 
más optimista, libre y con mayores recursos formales. Este espíritu revolucionario fue rápidamente asumido por los integrantes del grupo Huarte, constituyendo su seña de identidad.

El auge inmobiliario llevó a la familia Huarte a crear la sociedad HISA, con objeto de promover edificios comerciales de alta calidad, contando para ello con los mejores arquitectos españoles. El primer encargo fue el Edificio Torres Blancas (1958), símbolo de la labor creativa de la empresa, hecho realidad diez años más tarde. Los industriales contaron con Sáenz de Oíza gracias a la mediación de Oteiza, con quien había trabajado previamente en la Basílica de Aránzazu. (6) A partir de la Sala HISA todos los proyectos siguientes para Huarte se movieron en la órbita del organicismo, lenguaje común de los arquitectos del grupo Huarte a partir de entonces. Torres Blancas fue sin duda el edificio que más contribuyó en España al tránsito hacia el organicismo, pues conviene recordar que parte de su documentación gráfica fue publicada por vez primera en 1963, cinco años antes de finalizar la obra. (7)

Oíza generó decenas de dibujos con las variantes de cada una de las plantas del edificio. (8) Uno de los más interesantes es un dibujo coloreado (Fig. 9) donde hace resaltar unos pequeños círculos que recuerdan a los 'condensadores de luz' de Jorge Oteiza. Comparando estos primeros dibujos con los planos definitivos, (Fig. 10) puede comprobarse que entre ellos no existen grandes diferencias. También Oteiza realizó dibujos a partir de la geometría circular, que más tarde servirían de punto de partida para sus esculturas perforadas. Uno de ellos (Fig. 11) ofrece una visión superior, donde se juntan desordenadamente varios círculos sobrepuestos de diferentes tamaños. Su disposición y la relación entre ellos, recuerdan las plantas de Torres Blancas. (Fig. 12)

En el dibujo-collage La vía láctea, (Fig. 13) sitúa pequeños puntos blancos sobre la superficie oscura de la figura vertical, expresando su capacidad de ser focos de emisión de energía liberada. Como si fuese un árbol, a lo lar-

Oíza produced dozens of drawings with the variations for each floor in the building. (8) One of the most interesting is a colourful drawing (Fig. 9) which highlights some small circles reminiscent of Jorge Oteiza's 'condensers of light'. A comparison of these initial drawings with the final plans (Fig. 10) shows that there are no major differences between them. Oteiza also produced drawings based on the circular geometry which he would subsequently use as the starting point for his perforated sculptures. One of them (Fig. 11) provides a vision from above, in which several overlapping circles of different sizes converge untidily. Their layout and the relationship between them are reminiscent of the floors of Torres Blancas. (Fig. 12)

In the drawing-collage entitled The Milky Way, (Fig. 13) he places small white dots on the dark surface of the vertical figure, expressing their ability to be sources of emission for released energy. As if it were a tree, there are circular branches along the trunk that could be confused with added platforms or viewpoints. Curved lines protrude from its base, which resemble the roots that anchor it to the ground on which it rests. It is worthwhile recalling the parallel between Torres Blancas and tree-like structures, with its solid foundations, strong trunk and curved terraces act-

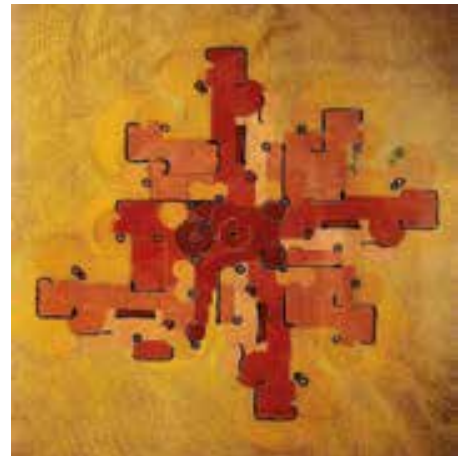

Fig. 9. Sáenz De Oíza, Fco. J.: Planta del edificio Torres Blancas, cera s/ papel, 1965.

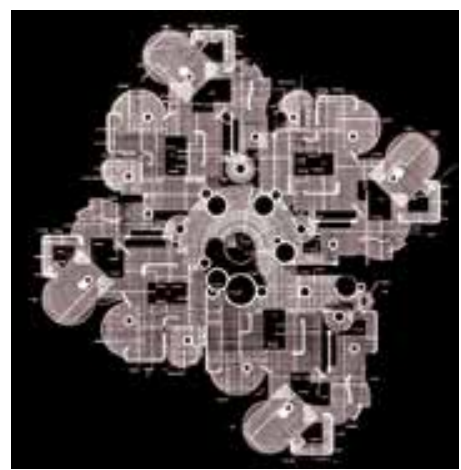

Fig. 10. Sáenz De Oíza, Fco. J.: Esquema de armaduras en forjado del edificio Torres Blancas, 1968.

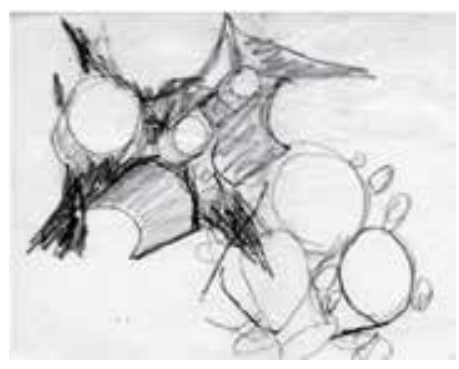

Fig. 11. Oteiza, Jorge: Dibujo. s. d. Archivo de la Fundación Museo Jorge Oteiza.

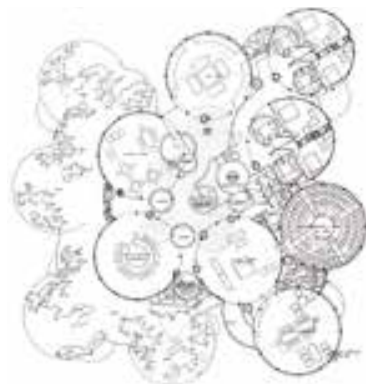

Fig. 12. Sáenz De Oíza, Fco. J.: Distribución de la planta 23 del edificio Torres Blancas, 1968. 
go del tronco dispone unas ramas circulares que podrían confundirse con plataformas o miradores añadidos. De su base salen unas líneas curvadas que semejan ser las raíces que le anclan a la tierra sobre la que descansa. No parece vano recordar el paralelismo establecido entre Torres Blancas y las estructuras arbóreas, con su sólida cimentación, su firme tronco y las terrazas curvilíneas a modo de ramas. Puede resultar un tanto inocente asegurar que la única influencia de la geometría circular de Torres Blancas surgió de los dibujos y esculturas de su amigo, aunque la enorme proximidad, complicidad y admiración mutuas produjo sus efectos en el trabajo de ambos. Oíza llegó a manifestar que Oteiza fue para él como su 'padre espiritual' y que en los escasos proyectos compartidos aprendió más que en ningún otro. (9)

La desocupación en Oteiza. A mediados de los años cincuenta Oteiza saltó a las formas geométricas puras -esferas, cilindros y cubos- al no ofrecer los 'condensadores de luz' la respuesta que él esperaba respecto a la liberación de energía en la estatua. Otro planteamiento parecía necesario. Y fue entonces cuando descubrió la existencia de los crómlech neolíticos en el Pirineo vasconavarro, unos pequeños círculos de piedras en el suelo, sin restos en su interior, cumpliendo funciones únicamente rituales o sagradas. Según Oteiza, estas construcciones actuaban como símbolos de la experiencia humana relativa a su destino, una síntesis equilibrada entre lo humano y lo divino. Para él, el artista contemporáneo debía recuperar esa relación íntima con las fuerzas del universo, para encontrar formas que tuviesen un significado espiritual y universal. El crómlech, pues, como ejemplificación de la relación del hombre con el cosmos.

A partir de entonces buscó la desocupación interior de sus esculturas como traslación conceptual de las construcciones crómlech. En Desocupación de la esfera (1957), (Fig. 14) la esencia de la escultura es el espacio interior vacío delimitado por las barras curvadas perimetrales, quedando establecido el volumen más por ausencia que por presencia. Cuando en 1965 Juan Daniel Fullaondo diseñó el despacho de Juan Huarte (10) estableció un juego expresionista de círculos sucesivos que, escalonados, dominaban en paredes, falsos techos y muebles, influido por las formas circulares con las que trabajó duran-
Fig. 13. Oteiza, Jorge: Estudio para la Vía Láctea. Estudio sobre 'condensadores de luz', c. 1955.

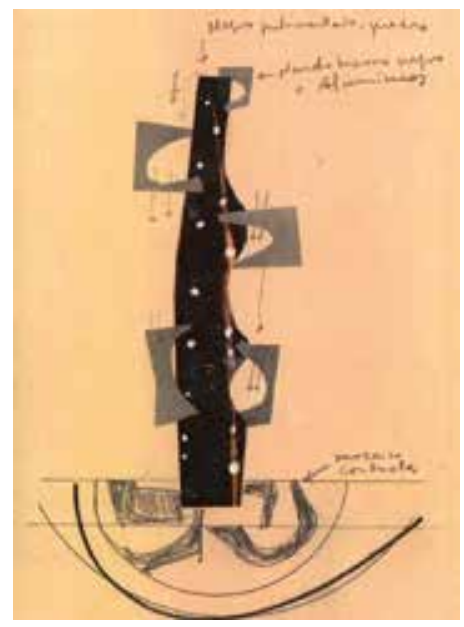

ing as branches. It may be somewhat naive to maintain that the only influence on the circular geometry of Torres Blancas came from his friend's drawings and sculptures, but the enormous mutual proximity, complicity and admiration had an effect on the work of both men. Oíza said that Oteiza was his 'spiritual father', and that he learned more than anywhere else during the few projects they worked on together. (9)

Oteiza and Disoccupation. In the mid-fifties, Oteiza moved on to pure geometric forms -spheres, cylinders and cubesas the 'condensers of light' did not provide the answer he anticipated about the release of energy in statues. Another approach appeared to be necessary. It was at this point that he discovered the existence of Neolithic stone circles in the Pyrenees in the Basque Country and Navarre, small circles of stones on the ground, with no remains inside, with only ritual or sacred functions. According to Oteiza, these constructions were symbols of human experience related to its destiny, a synthesis balanced between the human and the divine. He believed that the contemporary artist had to recover the intimate relationship with the forces of the universe to find forms that had a spiritual and universal meaning. The stone circle therefore exemplified the man's relationship with the cosmos.

Thereafter, he sought an inner disoccupation in his sculptures as a conceptual translation of the stone circle constructions. In Disoccupation of the Sphere (1957), (Fig. 14) the essence of the sculpture is the empty inner space defined by the curved bars on the perimeter, and the volume is established by an absence rather than by a presence. When Juan Daniel Fullaondo designed the office of Juan Huarte (10) in 1965, he created an expressionist series of successive staggered circles, which 
te su estancia en el estudio de Oíza. En el centro de la habitación se dispuso el elemento más importante, la pequeña escultura Desocupación de la esfera, (Fig. 15) sobre la que parecía orbitar todo el resto de la estancia. (11)

La desocupación del cubo ocupó la última etapa de su producción, generándose a partir de la representación de una figura cúbica cerrada y abierta al mismo tiempo. En la serie de 'cajas vacías', sobre varios de sus lados se recortaba una parte de su superficie permitiendo ver el interior hueco. Así, las seis planchas no solo definen con su presencia los límites exteriores de un cubo, sino que permiten apreciar su interior vacío o, mejor aún, conforman por sí mismas los límites del vacío. Lo importante no es la parte matérica sino aquello que el material delimita. (12) En sus manos las esculturas fueron simplificándose, diluyéndose en el vacío que guardaban en su interior hasta desaparecer.

Epílogo. Oteiza y el vacío de Le Corbusier. Es posible detectar ciertas influencias arquitectónicas en estas esculturas conclusivas de Oteiza, en especial a partir de algunas obras de Le Corbusier. El escultor sentía una particular
Fig. 14. Oteiza, Jorge: Desocupación de la esfera. Variante, 1957.

Fig. 15. Fullaondo, J.D.: interior del despacho de Juan Huarte en las oficinas HISA, 1965.
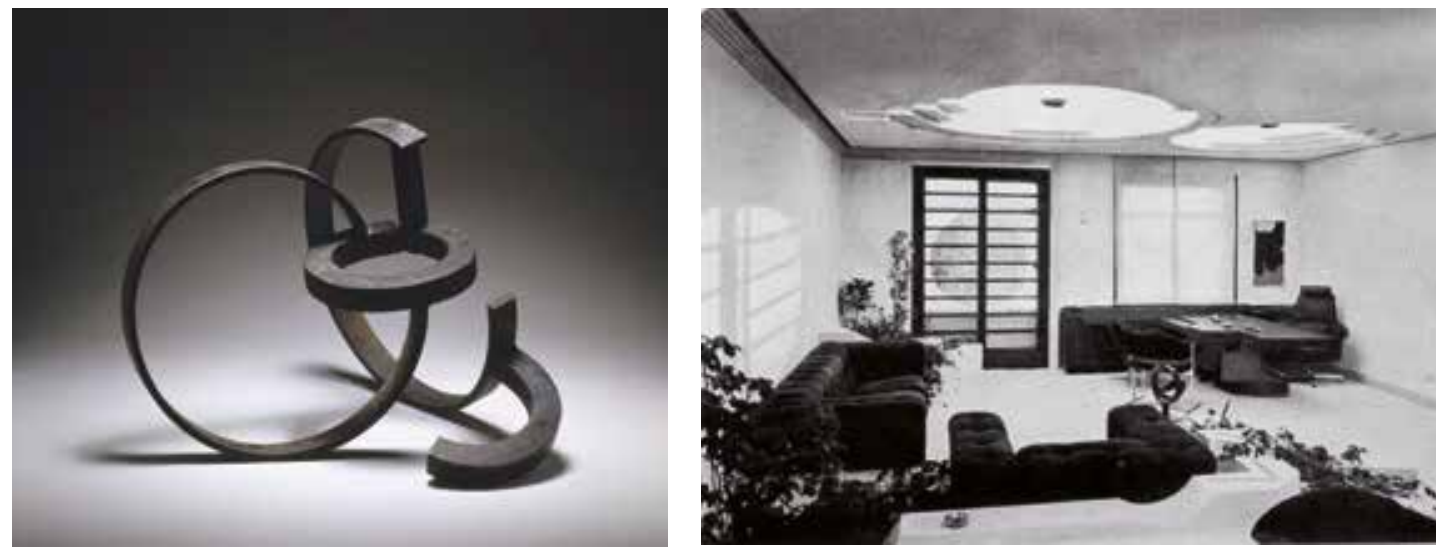

dominated the walls, false ceilings and furniture and were influenced by the circular shapes he worked with during his time at Oíza's studio. The most important element was placed in the centre of the room, the small sculpture Disoccupation of the Sphere, (Fig. 15) around which the rest of the room seemed to orbit. (11)

The disoccupation of the cube occupied the entire final phase of the production, and was created based on the representation of a cubic figure that was simultaneously closed and open. In the series of Empty Boxes, part of the surface was cut away on several of the sides, allowing the viewer to see the hollow interior. As a result, the six panels not only define the outer limits of a cube by their presence, but more importantly, they allow us to appreciate its inner emptiness, or indeed, they establish the limits of the void themselves. What is important is not the material part, but rather what the material defines. (12) Sculptures were simplified in his hands, and became diluted in the void inside them until they disappeared.

Epilogue. Oteiza and the Void of Le Corbusier. It is possible to identify certain architectural influences in these final sculptures by Oteiza, and especially from some works by Le Corbusier. The sculptor was particularly fascinated by the Chapel of Notre-Dame-du-Haut in Ronchamp, despite not belonging to the rationalist tendency with which he identified at that time. He sensed the end of a similar process to the one which he was experiencing with his sculptures, the proof that Le Corbusier, finally released, had concluded his time as an architect. He saw the relationship between the chapel and the final conclusive sculptures, in which the metaphysical or spiritual interior space is valued over the 
fascinación por la Capilla de Notre-Dame-du-Haut en Ronchamp, a pesar de no pertenecer a la tendencia racionalista con la que se sentía identificado por entonces. Intuía el final de un proceso similar al que él estaba viviendo con sus esculturas; la demostración de que Le Corbusier, por fin liberado, había concluido su fase de arquitecto. Veía la relación de la capilla con sus esculturas finales conclusivas, donde se valoraba el espacio interior metafísico o espiritual por encima del contenedor. Por otro lado, las pequeñas vidrieras coloreadas del gran muro curvo y sus reflejos desplazándose por el interior de la nave, parecían estar conectados con la investigación que estaba llevando a cabo sobre el espacio suprematista de Malevich y el concepto de 'pared-luz'.

En efecto, las vidrieras coloreadas de Le Corbusier proyectan zonas de luz al interior, inundando de color paredes y suelo de una forma jamás experimentada en ninguna de las obras anteriores, pues al hacer intervenir directamente los ciclos de luz solar, las formas de color se desplazan, se deforman y se sobreponen generando un dinamismo cromático que en sus pinturas tampoco había conseguido. Se establece así una relación muy directa con las maquetas vidriadas que Oteiza hizo para la Bienal de Sâo Paulo, a partir de la superposición de láminas de vidrio transparente que denominó Estudios de la ParedLuz, (Fig. 16) entre las que iba intercalando pequeñas cartulinas de colores, las 'unidades Malevich'. . Sustituyó, pues, la superficie blanca de los lienzos suprematistas por cristal trasparente; es decir, situó espacio entre las distintas 'unidades Malevich'. Éstas, flotantes y coloreadas, se relacionaban unas con otras según su posición azarosa en el vidrio y su profundidad relativa. Al aplicar la luz sobre la maqueta observó todas las posibilidades que su aplicación ofrecía, frente a las limitaciones planas de los lienzos. Oteiza descubrió que a la tercera dimensión se añadía una cuarta al introducir el movimiento del observador o cambios en la iluminación, de forma muy simular a lo que ocurre con la luz que entra por los pequeños vitrales coloreados de Ronchamp.

Por otro lado, en Ronchamp los muros este y sur no llegan a tocarse, permitiendo entre ambos un plano vertical de vidrio donde se sitúa uno de los accesos. Además, desde el interior se ve con claridad cómo los muros
Fig. 16. Oteiza, Jorge: Maquetas en vidrio para el Estudio de la Pared-Luz, 1956-58.

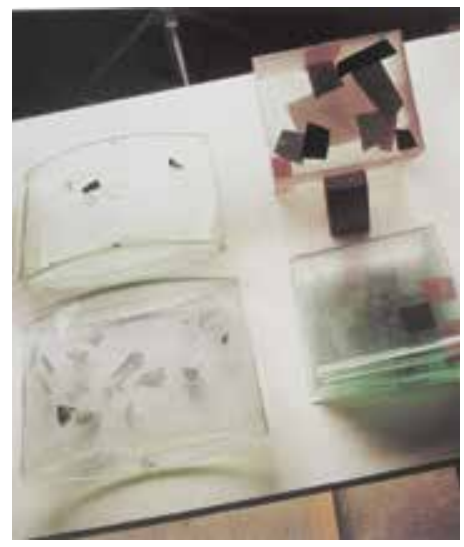

container. Meanwhile, the small stained-glass windows in the long curved wall, and their reflections moving along the inside of the nave, appeared to be connected with the research that he was undertaking on Malevich's Suprematist space and the concept of the 'wall-light'.

Indeed, Le Corbusier's stained-glass windows projected areas of light into the interior, inundating the walls and floor with colour in a manner unprecedented in any of the previous works. By making cycles of sunlight intervene directly, the forms of colour move, become distorted and overlap each other, creating a chromatic dynamism that he had not achieved in his paintings. This creates a very direct relationship with the glazed models that Oteiza produced for the Biennial of Sao Paulo, using overlapping layers of transparent glass which he called Studies of Wall-Light, (Fig. 16) among which he interspersed small coloured paper cards, the 'Malevich units'. This therefore replaced the white surface of the Suprematist paintings with transparent glass; in other words, it placed space between the different 'Malevich units'. These floating and coloured units were related to each other according to their random position in the glass and its relative depth. When light was applied to the model, he saw all the possibilities that their application offered, as compared to the flat limitations of canvas. Oteiza discovered that in addition to the third dimension, there was a fourth, which was the result of adding the movement of the observer or changes in the lighting, in a very similar way to what happens with the light that comes in through the small stained glass windows at Ronchamp. 


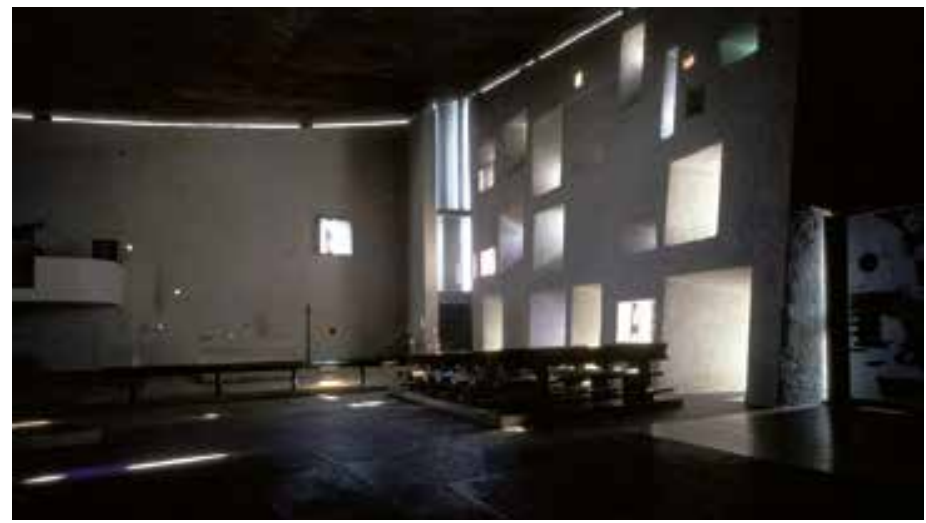

se desvinculan de la cubierta por una franja de luz, (Fig. 17) con la intención de acentuar la levedad de la gran masa de la cubierta y marcar así la ligereza del edificio. Esta misma formalización la llevará Oteiza a las Cajas Metafísicas (Fig. 18) donde el desplazamiento horizontal de uno de los dos triedros genera fisuras por donde entrever el vacío interior. Ambos llegan finalmente a un contenedor despojado y silente, apto para el recogimiento y la emoción.

De acuerdo a la mitología tejida alrededor de Jorge Oteiza, "No mueras sin ir a Ronchamp" fue el consejo que le dio a su amigo Oíza en la década de los años noventa. Finalmente éste decidió hacer un viaje por Francia, visitando la Capilla de Ronchamp y el Convento de La Tourette. La huella de este viaje puede apreciarse en muchos fragmentos de la Fundación Museo Oteiza en Alzuza, Navarra -diseñado por Oíza- como son los tres lucernarios sobre la sala de exposiciones, las rampas interiores, o las fenêtres en longeur. Se da la triste circunstancia que ninguno de los dos vivió lo suficiente para ver el edificio acabado.

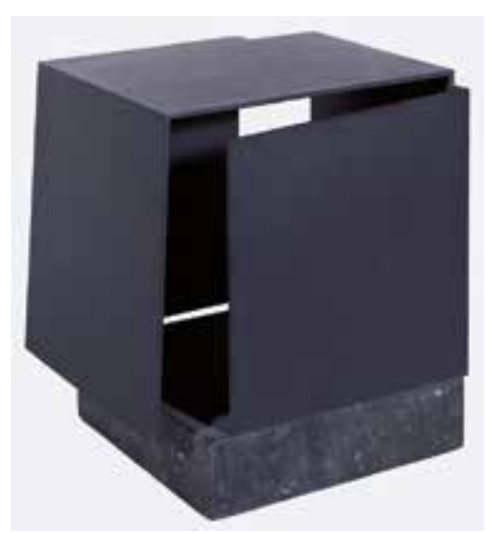

Fig. 17. Le Corbusier: Interior de la Capilla de Notre-Dame-du-Haut en Ronchamp, 1950-55. Fig. 18. Oteiza, Jorge: Caja metafísica, 1958-59.

Furthermore, the east and south walls at Ronchamp do not touch each other, allowing a vertical glass plane between them containing one of the entrances. In addition, it is readily apparent from the inside how the walls are separated from the roof by a strip of light, (Fig. 17) in order to emphasise the lightness of the great mass of the roof and thus highlight the lightness of the building. This same formalisation would lead Oteiza to the metaphysical boxes, (Fig. 18) in which the horizontal displacement of one of the two trihedrons creates fissures through which the inner void can be glimpsed. Both eventually reach a stripped and silent container, appropriate for contemplation and emotion.

According to the mythology created around Jorge Oteiza, "Do not die without going to Ronchamp" was the advice he gave to his friend Sáenz de Oíza in the early nineties. Sáenz de Oíza finally decided to go to France, visiting the Chapel of Ronchamp and the Convent of La Tourette. The impression this trip made on him can be seen in many fragments of the Oteiza Museum Foundation in Alzuza, Navarre, designed by Sáenz de Oíza, such as the three skylights above the exhibition hall, the interior ramps, and the fenetres en longeur. Sadly, neither man lived long enough to see the building completed. 


\section{NOTAS}

1. La imagen del domicilio de Juan Huarte pertenece a una serie de seis fotografías tomadas por Juan Dolcet en fecha sin determinar. Pertenecen a la carpeta 'Pablo Palazuelo I', procedente del archivo de la Galería Juana Mordó de Madrid. Donación de Helga de Alvear al Museo Nacional Centro de Arte Reina Sofía. Catalogación: Material Especial $6277, \mathrm{n}^{\circ}$ de registro 75749 .

2. La escultura fue construida en 1965 a partir de una maqueta de 1952 de título Prometeo múltiple. Formada por dos columnas de piedra de aproximadamente siete metros de altura, se encuentra en un alto de la finca que la familia Huarte posee cerca de Pamplona, dominando el bello paisaje navarro.

3. Juan Huarte estableció dos grandes similitudes entre la actividad del empresario y la del artista. Por un lado, ambos hacen de la invención continua el objeto de su vida; además, los dos asumen la experimentación como su método habitual de trabajo. En consecuencia, añade, lo esencial de quien ejerce el mecenazgo es sentir como propia la necesidad del artista de inventar y de experimentar. HUARTE, Juan. 'Acerca del mecenazgo', en: ROSALES, Alberto (ed.). Jorge Oteiza, creador integral. Pamplona: Universidad Pública de Navarra; Fundación Museo Oteiza, 1999. p. 151.

4. La Sala de Exposiciones HISA fue el segundo encargo de Huarte a Sáenz de Oíza y el primero en ser ejecutado. Situado en el edificio Huarte, en la entonces avenida del Generalísimo 8, contaba con acceso directo desde la calle y dos niveles bajo rasante. Acabada la obra, a finales de 1960, la primera publicación que se hizo eco de la sala fue la revista Arquitectura, n. 30, junio de 1961.

5.0TEIZA, Jorge. 'Informe sobre mi escultura'. Revista Cabalgata. Buenos Aires, 1946.

6. Sáenz de Oíza colaboró en sólo cuatro proyectos con Jorge Oteiza. Tras la Basílica de Aránzazu trabajaron juntos en la Capilla del Camino de Santiago, en el proyecto de la Alhóndiga de Bilbao (no construido) y en el de la Fundación Museo Oteiza en Alzuza (Navarra). 7.La primera revista que publicó Torres Blancas fue Hogar y Arquitectura n. 49, noviembre-diciembre 1963, en portada y pp. 17-40. 8. Entre el número 13 (febrero 1967) y el número 18 (julio 1967) la revista Nueva Forma (por entonces llamada Forma Nueva. El inmueble), propiedad de los Huarte, publicó seis separatas con dibujos de Torres Blancas hechos por Sáenz de Oíza.

9. Declaraciones de Sáenz de Oíza en una entrevista incluida en el documental No mueras sin ir a Ronchamp producido por RTVE.

Disponible en: [http://www.rtve.es/alacarta/videos/imprescindibles/ imprescindibles-no-mueras-sin-ir-ronchamp-saenz-oiza/2929434/]. 10. Proyecto publicado el mismo año de su ejecución en: FULLAONDO, Juan Daniel. 'Reforma de las oficinas de HISA (Huarte Inmobiliaria, S.A.)'. En: TA n. 77. Madrid, 1965. pp. 15-24

11. Con respecto a la relación entre la arquitectura y el arte, Oteiza escribió: "Solamente el hombre llega a habitar la arquitectura como construcción espiritual cuando el arte se integra en la arquitectura hasta fundirse, de tal modo que el arte -la estatua- desaparecen". OTEIZA, Jorge. Integración del Arte en la Arquitectura. S.d. Archivo Fundación Museo Oteiza, registro $\mathbf{n}^{\circ} \mathbf{8 0 0 8}$.

12. Las Cajas Vacías equivaldrían al desarrollo tridimensional de un cuadro suprematista de Malevich, donde los recortes en algunas de las seis caras del cubo equivalen a las figuras de sus cuadros. Hay que ver varias caras a la vez para entender la espacialidad suprematista de estas esculturas.

\section{NOTES}

1. The image of the home of Juan Huarte comes from a series of six photographs taken by Juan Dolcet on an unspecified date. They belong to the 'Pablo Palazuelo I' folder, from the archive of the Juana Mordo Gallery in Madrid. Donated by Helga de Alvear to the Museo Nacional Centro de Arte Reina Sofía. Catalogued: Special Material 6277 , registration number 75749 .

2. The sculpture was built in 1965 from a 1952 model entitled Multiple Prometheus. It consisted of two stone columns about seven meters tall, and is in the loft of an estate that the Huarte family owned near Pamplona, overlooking the beautiful Navarre landscape.

3. Juan Huarte established two major similarities between the work of the businessman and the artist. On the one hand, both make continuous invention their purpose in life; in addition, they both accepted that experimentation was their standard working method. Consequently, he adds, the essence of the person who provides patronage is to feel the artist's need to invent and experiment for themselves. HUARTE, Juan. 'Acerca del mecenazgo.' In: ROSALES, Alberto (ed.). Jorge Oteiza, creador integral. Pamplona: Public University of Navarre; Oteiza Museum Foundation, 1999. p. 151.

4. The HISA Exhibition Hall was Huarte's second commission to Saenz de Oíza, and the first to be executed. It was located in the Huarte building on what was then known as Generalisimo Avenue 8, and had direct access from the street, and two floors below ground level. The work was completed in late 1960, and the first publication to present the room was issue 30 of Arquitectura magazine, in June 1961.

5. OTEIZA, Jorge. 'Informe sobre mi escultura'. Cabalgata magazine. Buenos Aires, 1946.

6. Sáenz de Oíza worked with Jorge Oteiza on only four projects. After the Basilica of Aranzazu, they worked together on the Chapel of the Camino de Santiago, on the project for the Corn Exchange in Bilbao (which was not built) and the Oteiza Foundation Museum in Alzuza, Navarre.

7. The first magazine that published Torres Blancas was issue n. 49 of Hogar y Arquitectura, on November-December 1963, on the cover and on pages 17-40.

8. Between issue number 13 (February 1967) and number 18 (July 1967) the magazine Nueva Forma (which at that time was entitled: Forma Nueva. El inmueble), owned by the Huarte family, published six supplements with drawings of the Torres Blancas Building by Saenz de Oíza.

9. Comments by Saenz de Oíza in an interview in the documentary No mueras sin ir a Ronchamp produced by RTVE: [http://www.rtve. es/alacarta/videos/imprescindibles/imprescindibles-no-mueras-sinir-ronchamp-saenz-oiza/2929434/].

10. Project published in the year of its execution in: FULLAONDO, Juan Daniel. 'Reforma de las oficinas de HISA (Huarte Inmobiliaria, S.A.)', in: TA n. 77. Madrid, 1965. pp. 15-24

11. On the relationship between architecture and art, Oteiza wrote: "Man only inhabits architecture as a spiritual construction when art is integrated into the architecture until it merges, so that the art -the statuedisappears". OTEIZA, Jorge. Integración del Arte en la Arquitectura. S.d. Oteiza Museum Foundation Archive, registration number 8008 12. The empty boxes are the equivalent of the three-dimensional development of a Suprematist painting by Malevich, in which the cuts on some of the six faces of the cube correspond to the figures in his paintings. It is necessary to see several sides at once in order to understand the Suprematist spatiality of these sculptures. 


\section{REFERENCIAS}

AA.VV. Homenaje a D. Félix Huarte (Monográfico). Madrid: Colegio Oficial de Arquitectos de Madrid (COAM), n. 154, octubre 1971. FULLAONDO, Juan Daniel. 'Arte y decoración en el hogar del coleccionista Juan Huarte', Forma Nueva. El inmueble, n.9. Madrid, octubre 1966. FULLAONDO, Juan Daniel. 'Torres Blancas en la trayectoria de Francisco Javier Sáenz de Oíza', Forma Nueva. El inmueble, n. 10/11. Madrid, noviembre-diciembre 1966.

FULLAONDO, Juan Daniel. 'Un chalet en Puerta de Hierro', Nueva Forma, n. 20. Madrid, septiembre 1967.

HUARTE, Juan. 'Acerca del mecenazgo', en: ROSALES, Alberto (ed.). Jorge Oteiza, creador integral. Pamplona: Universidad Pública de Navarra; Fundación Museo Oteiza, 1999.

VENERO, Josu. Juan Huarte, el último mecenas. [DVD]. Bilbao: Art Frame, 2007.

\section{REFERENCIAS}

VV.AA. Homenaje a D. Félix Huarte (Monograph). Madrid: Colegio Oficial de Arquitectos de Madrid (COAM), n. 154, October 1971. FULLAONDO, Juan Daniel. 'Arte y decoración en el hogar del coleccionista Juan Huarte', Forma Nueva. El inmueble, n.9. Madrid, October 1966.

FULLAONDO, Juan Daniel. 'Torres Blancas en la trayectoria de Francisco Javier Sáenz de Oíza', Forma Nueva. El inmueble, n.10/11. Madrid, November-December 1966.

FULLAONDO, Juan Daniel. 'Un chalet en Puerta de Hierro', Nueva Forma, n.20. Madrid, September 1967.

HUARTE, Juan. 'Acerca del mecenazgo', ROSALES, Alberto (ed.). Jorge Oteiza, creador integral. Pamplona: Public University of Navarre; Oteiza Museum Foundation, 1999.

VENERO, Josu. Juan Huarte, el último mecenas. [DVD]. Bilbao: Art

Frame, 2007. 
